\title{
PENGARUH EMPLOYEE EMPOWERMENT DAN PSYCHOLOGICAL CONTRACT TERHADAP TURNOVER INTENTION DENGAN EMPLOYEE ENGAGEMENT SEBAGAI VARIABEL MEDIASI PADA PT BBI
}

\author{
Julianto Firman Lukmansyah dan Joyce Angelique Turangan \\ Program Studi Manajemen Fakultas Ekonomi dan Bisnis \\ Universitas Tarumanagara, Jakarta \\ E-mail: julianto.115170388@untar.ac.id
}

\begin{abstract}
The purpose of this study was to examine the effect of employee empowerment and psychological contract on turnover intention through employee engagement as a mediating variable at PT Buana Bersama Jayaindo. The sampling method used is nonprobability sampling with a purposive sampling approach. The data analysis technique used in this study is SEM-PLS and SMART PLS 3 program assistance. The results obtained are that employee engagement mediates the effect of employee empowerment and psychological contracts on employee turnover intention at PT Buana Bersama Jayaindo. Therefore, employee empowerment and psychological contract will be important factors to be evaluated in order to reduce turnover intention.
\end{abstract}

Keywords: employee empowerment, psychological contract, turnover intention, employee engagement.

\begin{abstract}
Abstrak: Tujuan dari penelitian ini adalah untuk menguji pengaruh employee empowerment dan psychological contract terhadap turnover intention melalui employee engagement sebagai variabel mediasi pada PT Buana Bersama Jayaindo. Metode pengambilan sampel yang digunakan adalah non-probability sampling dengan pendekatan purposive sampling. Teknik analisis data yang digunakan dalam penelitian ini adalah SEM-PLS dan bantuan program SMART PLS 3. Hasil yang didapatkan adalah bahwa Employee engagement memediasi pengaruh employee empowerment dan pscyhological contract terhadap turnover intention karyawan pada PT Buana Bersama Jayaindo. Oleh karena itu, employee empowerment dan pscyhological contract akan menjadi faktor yang penting untuk dievaluasi guna menurunkan turnover intention.
\end{abstract}

Kata Kunci: employee empowerment, psychological contract, turnover intention, employee engagement.

\section{LATAR BELAKANG}

Sumber daya manusia menjadi salah satu aspek terpenting dalam sebuah perusahaan. Hal ini dikarenakan sumber daya manusia adalah seluruh individu yang menjalankan kegiatan operasional dari sebuah perusahaan. Saat suatu perusahaan mengalami permasalahan pada sumber daya manusia mereka, maka hal tersebut akan sangat merugikan perusahaan. Namun sayangnya di Indonesia, tingkat turnover rate karyawan masih sangat tinggi. Dengan tingginya tingkat turnover rate ini menunjukkan bagaimana masalah turnover rate menjadi masalah dan celah yang belum bisa diselesaikan di Indonesia, dan hal ini membuat penelitian tentang turnover intention memang belum sepenuhnya menyelesaikan masalah turnover di Indonesia. 
Melihat dari adanya permasalahan yang belum terpecahkan tersebut, maka penelitian ini akan mencoba menyelesaikan masalah mengenai turnover intention karyawan di Perusahaan yang sedang mengalami permasalahan tersebut. Salah satu perusahaan yang mengalami masalah turnover intention adalah PT Buana Bersama Jayaindo, yaitu perusahaan tambak udang yang bekerja sehari-hari sebagai distributor udang ke beberapa daerah di Indonesia.

\section{KAJIAN TEORI}

Alsop dan Heinsohn (2005) mendefinisikan pemberdayaan karyawan (Employee Empowerment) sebagai proses peningkatan kapasitas yang dimiliki individu atau kelompok dalam sebuah organisasi untuk membuat sebuah pilihan serta untuk mengubah pilihan tersebut menjadi tindakan sehingga mencapai hasil yang diinginkan.

Menurut Sofyanty dan Setiawan (2020), Psychological contract diartikan sebagai keyakinan individu terhadap kewajiban timbal balik yang mungkin didapatkan karyawan, termasuk pengharapan atau ekspektasi kedua belah pihak yang secara implisit atau eksplisit telah dibuat.

Menurut Shuck dan Wollard (2011), employee engagement adalah keterlibatan karyawan yang didefinisikan sebagai proses memotivasi karyawan secara positif secara kognitif, emosional, dan perilaku untuk memenuhi hasil organisasi atau memberikan janji untuk mempertahankan dan bahkan meningkatkan keunggulan kompetitif diberbagai tingkatan organisasi.

Feng dan Angeline (2010) mengartikan turnover intention sebagai keinginan sadar berpikir, berkeinginan dan berencana meninggalkan pekerjaan. Quit intentions diartikan sebagai teknik kognitif mencari peluang kerja baru di institusi lain.

Kerangka pemikiran dalam penelitian ini sebagai berikut:

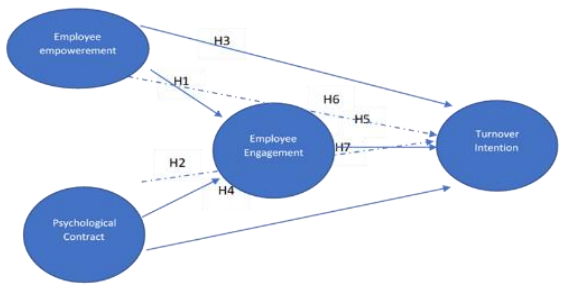

\section{Hipotesis:}

\section{Gambar 1. Kerangka Pemikiran}

Berdasarkan kerangka pemikiran yang terdapat di atas, maka hipotesis dalam penelitian ini adalah sebagai berikut:

H1: Employee empowerment berpengaruh positif terhadap employee engagement

$\mathrm{H} 2$ : Psychological contract berpengaruh positif terhadap employee engagement

H3: Employee Engagement berpengaruh negative terhadap turnover intention

H4: Employee empowerment secara langsung berpengaruh negative terhadap turnover intention

H5: Psychological contract secara langsung berpengaruh negative terhadap turnover intention

H6. Employee engagement memediasi pengaruh employee empowerment terhadap turnover intention

H7: Employee engagement memediasi pengaruh psychological contract terhadap turnover intention. 


\section{METODOLOGI}

Jenis riset yang digunakan adalah pengujian hipotesis atau testing hypothesis, dimana menurut Sekaran dan Bougie (2016), penelitian yang bersifat hypothesis testing dijalankan guna membuktikan kebenaran hipotesis-hipotesis dalam sebuah penelitian. Jenis penelitian yaitu penelitian kuantitatif. Dalam penelitian ini, yang menjadi populasi adalah karyawan PT Buana Bersama Jayaindo sejumlah 84 orang. Teknik pengumpulan data dalam penelitian ini menggunakan kuesioner. Aplikasi yang digunakan peneliti dalam penelitian ini adalah SmartPLS versi 3.3.3. Uji statistik yang digunakan dalam SmartPLS versi 3.3.3 adalah sebagai berikut:

Uji Validitas, menggunakan metode analisis reliabilitas menggunakan dasar Structural Equation Modeling (SEM) sebagai teknik analisis data. Analisis yang akan digunakan yakni inner dan outer model. Outer loading digunakan untuk mengetahui sejauh mana sebuah indikator mampu merefleksikan variabel dalam penelitian. Dalam uji partial least square, standarisasi untuk penilaian outer loadings adalah 0.7, sehingga, seluruh indikator yang memiliki nilai loadings $>0.7$ berarti telah mampu merefleksikan variabel laten. (Ramayah et al, 2018). Average Variances Exctracted digunakan untuk mengetahui validitas dari setiap variabel yang diteliti. Validitas artinya kemampuan alat ukur untuk mencerminkan data yang diteliti. Dalam uji partial least square, standarisasi untuk penilaian Average Variances Exctracted adalah 0.5, sehingga, setiap variabel laten yang memiliki nilai Average Variances Exctracted $>0.5$ berarti telah mampu memenuhi persyaratan Average Variances Exctracted. (Ramayah et al, 2018).

Uji reliabilitas pada penelitian ini dilakukan dengan melihat nilai dari Cronbach's Alpha dan Composite Reliability dari masing-masing variabel. Untuk dapat dikatakan reliabel, nilai Cronbach's Alpha harus lebih besar dari 0,5 dan nilai Composite Reliability lebih besar dari 0,6. Selanjutnya, untuk hasil analisis data dapat dilakukan pengujian sebagai berikut:

1. Cronbach's Alpha juga digunakan untuk mengetahui reliabilitas dari setiap variabel yang diteliti. Dalam uji partial least square, standarisasi untuk penilaian Cronbach's Alpha adalah 0.6, sehingga, setiap variabel laten yang memiliki nilai Cronbach's Alpha > 0.6 berarti telah mampu memenuhi persyaratan Cronbach's Alpha. (Ramayah et al, 2018)

2. Dalam uji partial least square, standarisasi untuk penilaian Composite Reliability adalah 0.6, sehingga, setiap variabel laten yang memiliki nilai Composite Reliability > 0.6 berarti telah mampu memenuhi persyaratan Composite Reliability. (Ramayah et al, 2018).

3. Pengujian hipotesis dilakukan untuk mengetahui adanya hubungan signifikan antara variabel dependen dan independen. Pada partial least square, untuk menguji hipotesis digunakan perhitungan bootstrapping. (Ramayah et al, 2018) uji hipotesis juga bisa digunakan untuk membentuk persamaan regresi dengan pengujian: Jika prob $\leq 0.05$, maka variabel bebas berpengaruh signifikan terhadap variabel terikat Jika prob > 0.05, maka variabel bebas tidak berpengaruh terhadap variabel terikat. 


\section{HASIL ANALISIS DATA}

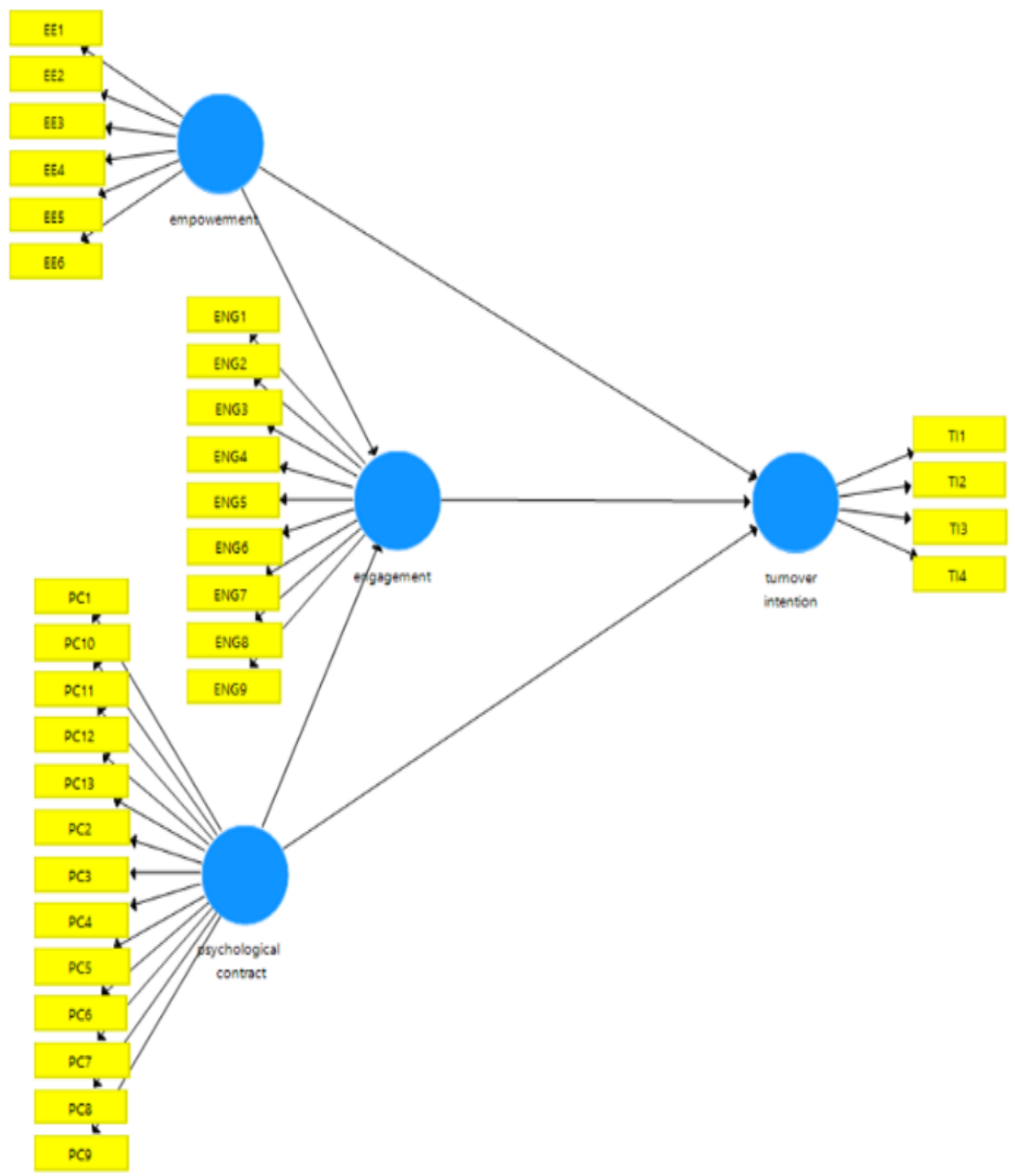

Gambar 2. Diagram Struktural 


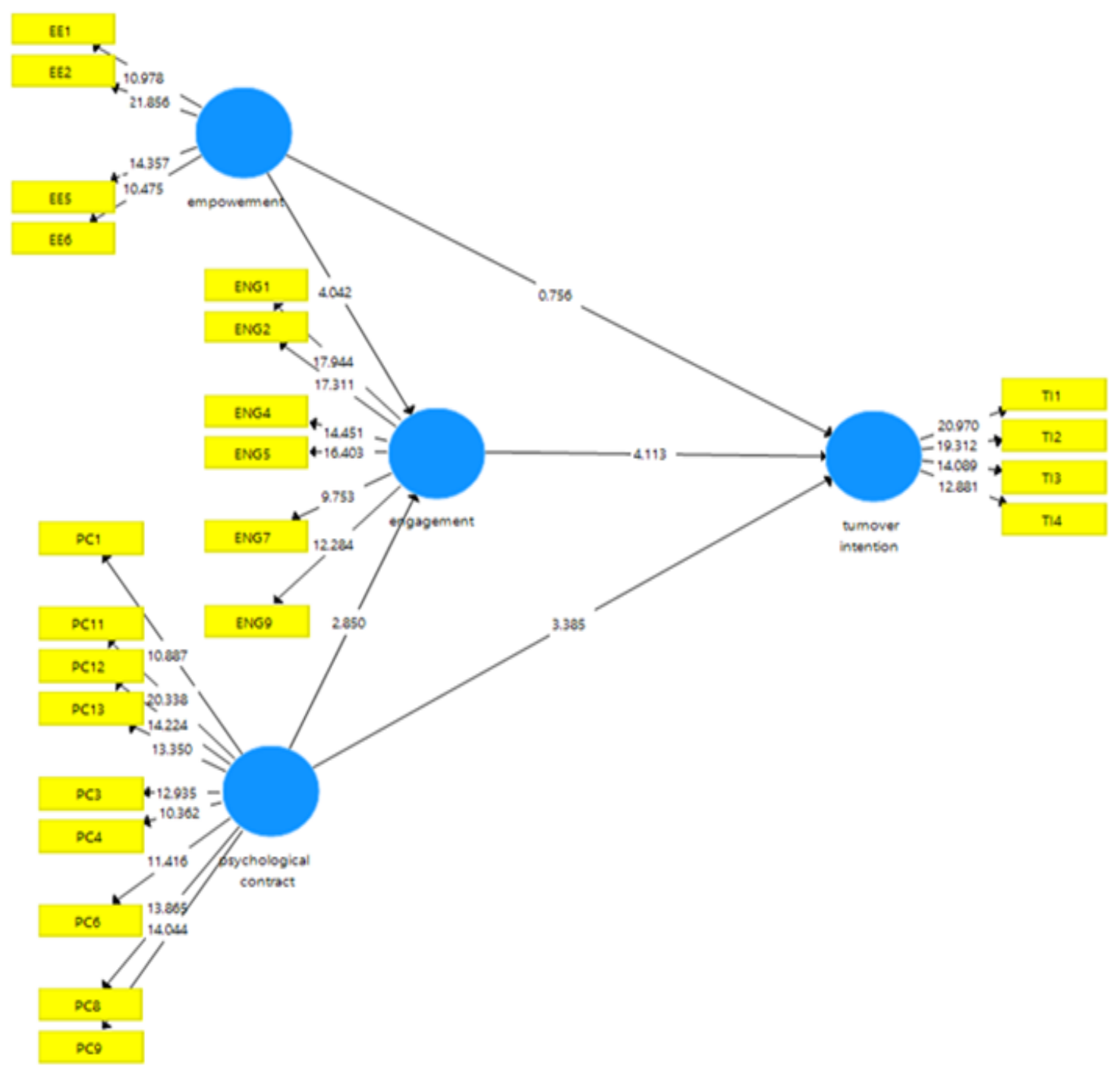

Gambar 3. Path Coefficients

Penulis akan membahas tentang hasil pengolahan data dengan software SmartPLS berdasarkan gambar di atas:

1. Path Coefficients

\begin{tabular}{|c|c|}
\hline Employee Empowerment -> Employee Engagement & 0.511 \\
\hline Psychological Contract -> Employee Engagement & 0.378 \\
\hline Employee Engagement -> Turnover Intention & -0.461 \\
\hline Employee Empowerment -> Turnover Intention & -0.092 \\
\hline Psychological Contract -> Turnover Intention & -0.378 \\
\hline $\begin{array}{c}\text { Employee Empowerment -> Employee Engagement } \\
\text {-> Turnover Intention }\end{array}$ & -0.236 \\
\hline $\begin{array}{c}\text { Psychological Contract -> Employee Engagement - } \\
\text { > Turnover Intention }\end{array}$ & -0.174 \\
\hline
\end{tabular}

Employee empowerment berpengaruh positif terhadap employee engagement dengan nilai koefisien $=0.511$ yang berarti jika variabel employee empowerment meningkat, maka akan meningkatkan nilai variabel employee engagement. Psychological Contract berpengaruh positif terhadap Employee Engagement dengan nilai 
koefisien $=0.378$ yang berarti jika variabel Psychological Contract meningkat, maka akan meningkatkan nilai variabel employee engagement.

2. Normed Fit Index (NFI)

\begin{tabular}{|r|r} 
NFI & $\mathbf{0 . 6 4 0}$
\end{tabular}

Dari tabel di atas, telrihat nilai NFI $=0.640$, dimana nilai tersebut berada pada rentang 0 sampai 1 , yang berarti model yang terbentuk sudah memenuhi kriteria Normed Fit Index.

3. $Q$-Square

\begin{tabular}{|c|c|}
\hline Dependent Variable & Q-Square \\
\hline Employee Engagement & 0.399 \\
\hline Turnover Intention & 0.478 \\
\hline
\end{tabular}

Dari tabel $q$-square di atas, maka dapat disimpulkan bahwa nilai $q$-square $=0.399$ dan 0.478 yang berarti nilai $q$-square tersebut berada di atas nilai 0 , sehingga model penelitian yang terbentuk telah memenuhi persyaratan dari $q$-square.

4. F-Square

\begin{tabular}{|c|c|c|}
\hline & Engagement & Turnover intention \\
\hline Empowerment & 0.298 & 0.009 \\
\hline Engagement & & 0.255 \\
\hline Psychological contract & 0.163 & 0.169 \\
\hline
\end{tabular}

$F$-square di atas, terlihat bahwa nilai $f$-square employee empowerment terhadap engagement $=0.298$ yang berada di atas 0.15 dan yang berarti $f$ square antara employee empowerment terhadap engagement dikategorikan sedang. Nilai $f$-square employee empowerment terhadap turnover intention $=0.009$ yang berada di bawah 0.02 yang berarti $f$-square antara employee empowerment terhadap turnover intention dikategorikan tidak lolos.

5. Uji Hipotesis

\begin{tabular}{|c|c|c|}
\hline Konstruk & T-Statistics & P-Value \\
\hline $\begin{array}{c}\text { Employee Empowerment -> Employee } \\
\text { Engagement }\end{array}$ & 4.042 & 0.000 \\
\hline $\begin{array}{c}\text { Psychological Contract -> Employee } \\
\text { Engagement }\end{array}$ & 2.850 & 0.005 \\
\hline $\begin{array}{c}\text { Employee Engagement -> Turnover } \\
\text { Intention }\end{array}$ & 4.113 & 0.000 \\
\hline $\begin{array}{c}\text { Employee Empowerment -> Turnover } \\
\text { Intention }\end{array}$ & 0.756 & 0.450 \\
\hline $\begin{array}{l}\text { Psychological Contract -> Turnover } \\
\text { Intention }\end{array}$ & 3.385 & 0.001 \\
\hline $\begin{array}{l}\text { Employee Empowerment -> Employee } \\
\text { Engagement -> Turnover Intention }\end{array}$ & 2.917 & 0.000 \\
\hline $\begin{array}{l}\text { Psychological Contract }->\text { Employee } \\
\text { Engagement }->\text { Turnover Intention }\end{array}$ & 2.153 & 0.032 \\
\hline
\end{tabular}

Dari tabel di atas dapat dijabarkan pengujian hipotesis sebagai berikut:

a $\quad \mathbf{H}_{\mathbf{1}}$ : Nilai $t$-statistic pada hipotesis pertama sebesar 4.042, lebih besar dari 1,96 dengan nilai pvalue $=0.000(<0.05)$ Sehingga dapat disimpulkan bahwa hipotesis diterima dan tidak ditolak, Artinya employee empowerment berpengaruh positif terhadap employee engagement

b $\quad \mathbf{H}_{2}$ : Nilai $t$-statistic pada hipotesis kedua sebesar 2.850, lebih besar dari 1,96 dengan 
nilai pvalue $=0.005(<0.05)$ Sehingga dapat disimpulkan bahwa hipotesis diterima dan tidak ditolak, Artinya Psychological contract berpengaruh positif terhadap employee engagement.

c $\quad \mathbf{H}_{3}$ : Nilai $t$-statistic pada hipotesis ketiga sebesar 2.850, lebih besar dari 1,96 dengan nilai pvalue $=0.005(<0.05)$ Sehingga dapat disimpulkan bahwa hipotesis diterima dan tidak ditolak, Artinya Psychological contract berpengaruh positif terhadap employee engagement.

d $\quad \mathbf{H}_{\mathbf{4}}$ : Nilai $t$-statistic pada hipotesis keempat sebesar 0.756 , lebih kecil dari 1,96 dengan nilai pvalue $=0.450(<0.05)$ Sehingga dapat disimpulkan bahwa hipotesis tidak diterima dan ditolak, Artinya Employee empowerment secara langsung tidak berpengaruh terhadap turnover intention

e $\quad$ H5 $_{5}$ : Nilai $t$-statistic pada hipotesis kelima sebesar 3.385, lebih besar dari 1,96 dengan nilai pvalue $=0.001(<0.05)$ Sehingga dapat disimpulkan bahwa hipotesis diterima dan tidak ditolak, artinya psychological contract secara langsung berpengaruh negative terhadap turnover intention

f $\quad \mathbf{H}_{6}$ : Nilai $t$-statistic pada hipotesis keenam sebesar 2.917, lebih besar dari 1,96 dengan nilai pvalue $=0.000(<0.05)$ Sehingga dapat disimpulkan bahwa hipotesis diterima dan tidak ditolak, artinya employee engagement memediasi pengaruh employee empowerment terhadap turnover intention

g $\quad \mathbf{H}_{7}$ : Nilai $t$-statistic pada hipotesis ketujuh sebesar 2.153, lebih besar dari 1,96 dengan nilai pvalue $=0.032(<0.05)$ Sehingga dapat disimpulkan bahwa hipotesis diterima dan tidak ditolak, artinya employee engagement memediasi pengaruh psychological contract terhadap turnover intention

\section{PEMBAHASAN}

Pada bagian ini akan dibahas mengenai hasil penelitian yang dilakukan pada karyawan pada PT Buana Bersama Jayaindo dengan pengambilan sampel sebanyak 74 responden penelitian. Pada penelitian ini terdapat tujuh hipotesis mengenai variabel yang digunakan, hasil dari penelitian ini adalah:

\section{Pengaruh Employee empowerment terhadap employee engagement}

Dari hasil analisis ditemukan bahwa nilai $t$-statistic pada hipotesis pertama sebesar 4.042, lebih besar dari 1,96 dengan nilai pvalue $=0.000(<0.05)$ Sehingga dapat disimpulkan bahwa hipotesis diterima dan tidak ditolak, Artinya employee empowerment berpengaruh positif terhadap employee engagement.

\section{Pengaruh Psychological Contract terhadap employee engagement}

Dari hasil analisis ditemukan bahwa nilai $t$-statistic pada hipotesis kedua sebesar 2.850 , lebih besar dari 1,96 dengan nilai pvalue $=0.005(<0.05)$ Sehingga dapat disimpulkan bahwa hipotesis diterima dan tidak ditolak, Artinya Psychological contract berpengaruh positif terhadap employee engagement.

\section{Pengaruh employee engagement terhadap turnover intention}

Dari hasil analisis ditemukan bahwa nilai t-statistic pada hipotesis ketiga sebesar 2.850, lebih besar dari 1,96 dengan nilai pvalue $=0.005(<0.05)$ Sehingga dapat disimpulkan bahwa hipotesis diterima dan tidak ditolak, Artinya Psychological contract berpengaruh positif terhadap employee engagement.

\section{Pengaruh employee empowerment terhadap turnover intention}

Dari hasil analisis ditemukan bahwa nilai t-statistic pada hipotesis keempat sebesar 0.756, lebih kecil dari 1,96 dengan nilai pvalue $=0.450(<0.05)$ Sehingga dapat disimpulkan bahwa hipotesis tidak diterima dan ditolak, Artinya Employee empowerment secara langsung tidak berpengaruh terhadap turnover intention

\section{Pengaruh psychological contract terhadap turnover intention}


Dari hasil analisis ditemukan bahwa nilai $t$-statistic pada hipotesis kelima sebesar 3.385, lebih besar dari 1,96 dengan nilai pvalue $=0.001(<0.05)$ Sehingga dapat disimpulkan bahwa hipotesis diterima dan tidak ditolak, artinya psychological contract secara langsung berpengaruh negative terhadap turnover intention

\section{Peranan Employee engagement dalam memediasi pengaruh employee empowerment terhadap turnover intention}

Dari hasil analisis ditemukan bahwa nilai $t$-statistic pada hipotesis keenam sebesar 2.917, lebih besar dari 1,96 dengan nilai pvalue $=0.000(<0.05)$ Sehingga dapat disimpulkan bahwa hipotesis diterima dan tidak ditolak, artinya employee engagement memediasi pengaruh employee empowerment terhadap turnover intention.

\section{Peranan Employee engagement dalam memediasi pengaruh psychological contract terhadap turnover intention}

Dari hasil analisis ditemukan bahwa nilai $t$-statistic pada hipotesis ketujuh sebesar 2.153, lebih besar dari 1,96 dengan nilai pvalue $=0.032(<0.05)$ Sehingga dapat disimpulkan bahwa hipotesis diterima dan tidak ditolak, artinya employee engagement memediasi pengaruh psychological contract terhadap turnover intention

\section{KESIMPULAN}

Berdasarkan hasil analisis yang peneliti teliti, maka dapat ditarik kesimpulan sebagai berikut:

1. Employee empowerment berpengaruh positif terhadap employee engagement karyawan pada PT Buana Bersama Jayaindo

2. Psychological contract berpengaruh positif terhadap employee engagement karyawan pada PT Buana Bersama Jayaindo

3. Psychological contract berpengaruh positif terhadap employee engagement karyawan pada PT Buana Bersama Jayaindo

4. Employee empowerment secara langsung tidak berpengaruh terhadap turnover intention karyawan pada PT Buana Bersama Jayaindo

5. Psychological contract secara langsung berpengaruh negative terhadap turnover intention karyawan pada PT Buana Bersama Jayaindo

6. Employee engagement memediasi pengaruh employee empowerment terhadap turnover intention karyawan pada PT Buana Bersama Jayaindo

7. Employee engagement memediasi pengaruh psychological contract terhadap turnover intention karyawan pada PT Buana Bersama Jayaindo

Berdasarkan dari hasil penelitian yang telah dilakukan, peneliti akan memberikan beberapa saran atau masukan yang sekiranya dapat digunakan atau bermanfaat bagi perusahaan maupun kepada penelitian selanjutnya, sebagai berikut:

a. PT. Buana Bersama Jayaindo dapat mengevaluasi kembali seluruh faktor pada employee empowerment dengan cara mengikutsertakan seluruh karyawan dalam segala kegiatan perusahaan, perusahaan juga bisa mengadakan event yang melibatkan kemampuan dari karyawan seperti memberikan hadiah kepada karyawan yang mampu melakukan pekerjaan diluar yang diharuskan, serta menerapkan sistem kepemimpinan yang sifatnya transformasional atau pemimpin yang terfokus pada pemberian motivasi dengan wibawa yang dimiliki. Selain itu perusahaan juga perlu memperhatikan seluruh faktor pada variabel psychological contract seperti memperhatikan karyawan-karyawan yang selalu 
maksimal dalam bekerja walaupun tidak menjadi kewajiban mereka, memerhatikan karyawan yang rela untuk lembur. Karyawan-karyawan tersebut dapat diberikan apresiasi lebih karena mereka memiliki psychological contract yang kuat terhadap perusahaan. Dengan peningkatan pada kedua hal di atas, diharapkan perusahaan akan mampu meningkatkan kembali employee engagement dan secara tidak langsung akan menurunkan turnover intention karyawan pada PT Buana Bersama Jayaindo.

b. Untuk penelitian selanjutnya, dapat dilakukan penelitian dalam skala yang lebih besar seperti dalam skala industrial dengan jumlah sampel dan subjek penelitian yang lebih banyak. Penelitian selanjutnya juga dapat meneliti variabel-variabel lain yang diduga bisa berpengaruh terhadap kepuasan kerja karyawan diluar variabel lingkungan kerja, motivasi kerja dan kompensasi seperti variabel stres kerja, komunikasi, locus of control dan sebagainya.

\section{DAFTAR PUSTAKA}

Al-Dmour, Hani., Yassine, Omayma dan Al-Dmour, Rand. (2019). The Impact of Employee Empowerment upon Sales Workforce Performance via the Mediating Role of Work Engagement in the Five Stars Hotels: Empirical Study. Journal of International Business and Management 2(2): 1-22.

Calecas, J. Kristina. (2019). Job Satisfaction, Employee Engagement, and Turnover Intention in Federal Employment. Walden Dissertations and Doctoral Studies Collection.

Feng, C. W., \& Angeline, T. (2010). Turnover intention and job hopping behaviour of music teachers in Malaysia. African Journal of Business Management. 4(4), pp. 425-434. ISSN 1993-8233

Hartanto, V. C., \& Turangan, J. A. Pengaruh Lingkungan Kerja, Kepemimpinan, Dan Kompensasi Kepuasan Kerja Pegawai Hotel Di Jakarta. Jurnal Manajerial Dan Kewirausahaan, 3(2), 518-527.

Prisillya, T., \& Turangan, J. A. Pengaruh Kepuasan Kerja, Stres Kerja, Dan Lingkungan Kerja Terhadap Niat Untuk Berpindah. Pengaruh Kepuasan Kerja, Stres Kerja, Dan Lingkungan Kerja Terhadap Niat Untuk Berpindah.

Putra, R. H., \& Turangan, J. A. Pengaruh Job Satisfaction Dan Organizational Commitment Terhadap Organizational Citizenship Behavior Pada Karyawan PT. Indec Diagnostics Jakarta. Jurnal Manajerial Dan Kewirausahaan, 2(4), 1070-1078.

Sharma, Naman dan Garg, Pratibha. (2017). Psychological Contract and Psychological Empowerment as Employee Engagement Drivers in Indian IT Sector. International Journal of Applied Business and Economic Researc 